\title{
SĪBAWAYHI'S OBSERVATIONS ON ASSIMILATORY PROCESSES AND RE-SYLLABIFICATION IN THE LIGHT OF OPTIMALITY THEORY*
}

\author{
Lutz Edzard
}

BONN

\begin{abstract}
The last seven chapters (chs. 565-71) of Sïbawayhi's Kitāb contain many phonetic and phonological observations that can be conveniently recast in terms of theories of linguistic preference and natural generative phonology (Hooper 1976), notably in terms of the approach of Vennemann $(1983,1988)$. Optimality Theory (Prince and Smolensky 1993) offers a formal means to capture the "constraint ranking" that is implicit in Sïbawayhi's rejection of disallowed forms and evaluation of parallelly occurring and competing forms ("candidates"). The relevant phenomena under investigation in this paper are mainly assimilatory processes but also re-syllabification and haplological syllable ellipsis.
\end{abstract}

\section{Introduction}

There has evolved quite a tradition of drawing lines of comparison between the theories in the "classical" linguistic literature and their modern counterparts. Carter (1973) has shown that Sïbawayhi's binary syntactic nomenclature may well be considered a spiritual forerunner of modern transformational grammatical theory, or rather constituent analysis. In this paper I attempt to show that Sìbawayhi's observations on phonetics and phonology may likewise be considered a forerunner of theories of linguistic preference, the most recent and widespread being Optimality Theory as developed by

\footnotetext{
* This paper is based on a presentation at the 20th Conference of the Union Européenne des Arabisants et Islamisants in Budapest (September 14, 2000). The author wishes to thank the Alexander von Humboldt foundation and the University of Oslo for support of this research and is grateful to Michael G. Carter and Theo Vennemann for useful comments. Quotations of Sībawayhi's Kitāb in this paper follow the Hārūn edition and the Internet site by M. Carter, A. Matveev, and L. Edzard: http://www.hf.uio.no/east/sibawayhi/HomePage/index.htm (numbers in brackets refer to the 77 segments of chs. 565-71 in the "Base Text" as well as the reproduced printed versions and manuscripts of the text). On the history of the text and the various problems of editing Sỉbawayhi's Kitāb, cf. Humbert 1995 and Carter 1997b. Quotations in this paper such as Q x:y refer to 'a ayya y of süra x in the Qur ān.
} 
Prince and Smolensky (1993). The "spiritual" relationship between Sĩbawayhi's observations and modern theoretical approaches will be demonstrated with special focus on the central tenets of Optimality Theory, ${ }^{1}$ but also with reference to other approaches of linguistic naturalness, one prominent example being Vennemann's theory of Preference Laws for Syllable Structure $(1983,1988){ }^{2}$

Most of Sïbawayhi's observations are found in the last seven chapters (chs. 565-71) of his Kitāb, all of which have the topic of 'idgām "assimilation" (literally: "insertion") as a common denominator. ${ }^{3}$ After a description of the hurüf "letters" ("phonemes") in chapter 565, Sïbawayhi sets out to investigate various assimilation phenomena, both word-internally and across word boundaries. These assimilation phenomena operate on both the segmental and the suprasegmental level. The latter relates especially to the spreading of velarization ("emphasis", A[dvanced] T[ongue] R[oot]), the corresponding Arabic terms being tafhìm ("velarization") and tarqīq ("develarization"). ${ }^{5}$ Sìbawayhi's term ${ }^{~} i d \dot{g} \bar{a} m$ covers both what we would call partial or total assimilation and what we would call haplological syllable ellipsis. While some of the forms quoted by him appear to be valuable traces

\footnotetext{
${ }^{1}$ Comments on Optimality Theory in this paper follow for the most part the general orientation of McCarthy and Prince 1994 and Kager 1999. To date this theory has witnessed quite a number of interesting applications to Arabic, especially modern Arabic dialects. Cf., for instance, Zawaydeh 1997 on epenthesis and syncope.

2 An application of this theory to Semitic phonology in general was attempted in Edzard 1991.

${ }^{3} \mathrm{Cf}$. Fleisch 1971 on the use of the term ${ }^{\circ} i d \dot{g} \bar{a} m$ (or iddig $\bar{a} m$ ) with the Arab grammarians. Síbawayhi in this context also makes use of the terms ${ }^{\circ} i b d \bar{a} l$ "replacement" and 'ihfa $\bar{c}$ "concealing". Cf. Al-Nassir 1993:56-58. As with later Arab grammarians, more material on phonological issues is found in chapters on weak verbs and nouns, verbs mediae or tertiae geminatae $\left(\mathrm{C}_{2}=\mathrm{C}_{3}\right.$ or doubled $\left.\mathrm{C}_{3}\right)$, ${ }^{\circ}$ alif/hamza, metathesis, and assimilation in different contexts. Cf. also Jahn (1969), vol. 2:550 (n. 15). The wealth of forms observed by Sïbawayhi has been the subject of a thorough study by Al-Nassir (1993), previously cited in this note. Cf. also the meticulous study of Ibn Jinnī's treatment of Arabic phonetics and phonology that was carried out by Bakalla (1982), not to forget historical forerunners like Schaade (1911), Bravmann (1934), Fleisch (1958a), and Semaan (1968), among others.

${ }^{4}$ Cf. Troupeau's (1958) analysis of al-Sīrāfī's commentary on chapter 565.

${ }^{5}$ On the issue of suprasegmental assimilation (ATR-spreading) in Semitic, cf. Hoberman 1989 and 1995, with further references.
} 
of old Arabic dialects, ${ }^{6}$ some phonologically reduced forms have also become part of the standard language, so that it is not surprising to find them even in the Qur ${ }^{\circ} a \bar{n}$. Usually such forms involve the imperfect form (second person) of form $\mathrm{V}^{7}$ or a suffix pronoun of the first person sg. or pl. attached

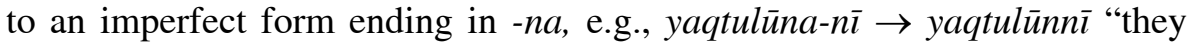
(m.) kill me".

Sībawayhi is not explicitly concerned with linguistic diachrony. ${ }^{8}$ However, many of the forms cited by him may reasonably be assumed to reflect a linguistic stage that is the result of various "remedial" strategies in language development as opposed to older more "classical" forms associated with the literary koine of the Arab poets. ${ }^{9}$

As is well known, language can be described in either descriptive or pre-

\footnotetext{
6 On this question cf. Levin 1994 and 1999.

${ }^{7}$ Examples in the Qurª̄n include: tatamannawna "you (m. pl.) wish" $\rightarrow$ tamannawna (Q 3:143); yatadakkarūna "they (m.) mention" $\rightarrow$ yaddakkarūna (Q 6:126); yatațyyarū "let them (m.) see a bad omen" $\rightarrow$ yațayyarū (Q 7:131); tatanazzalu "come(s) down", being the predicate of a non-human subject noun in the plural $\rightarrow$ tanazzalu (Q 97:4).

8 A useful discussion of the psychological reality of "underlying" forms is found in Bohas and Guillaume 1984, vol. 1. Cf. also Versteegh 1997:86.

${ }^{9}$ For a summarizing discussion of the issues of diglossia and polyglossia, cf. Hary 1992:29-47. In the case of Arabic and other Semitic languages, not only the perceived surface forms but also the orthography itself reveals an intrinsic ranking of constraints. It is important to note that many of the forms adduced by Sỉbawayhi are spoken forms that are not necessarily acceptable as such in writing. It is, however, not always clear how forms are to be pronounced, and even the very phonetic quality of certain consonants constitutes a problem. This problem is, for instance, at the core of the majhüra-mahmūsa controversy (cf., e.g., Fleisch 1958b and Odisho 1988). The opposition majhūra "voiced" vs. mahmūs "unvoiced" seems to be "disturbed" as the letters ("phonemes") represented by the graphemes $<$ t $>,<q>$ (and also $\left.<^{\supset}\right\rangle$ ) belong to the majhūra class in Síbawayhi's system (their modern pronunciation is unvoiced). For Sỉbawayhi, /ț/ is clearly [+voiced, +velarized], i.e., precisely the sound nowadays associated with /d/; /q/, which for Sībawayhi was the sound nowadays associated with $/ \mathrm{g} /$, is likewise [+voiced]. Another problem is the amount of differences in the extant manuscripts and editions. In the last seven chapters of the Kitāb this concerns mainly the phonemes /ț/, /ḍ/, and /ẓ/ (cf. Steiner 1977 on the quality of /d/). Also, some copyists seem not to have understood the very point and substance of the forms that Sïbawayhi represents as (graphically) compound forms and thus have replaced them by (graphically) separated forms without the relevant assimilation features.
} 
scriptive terms. Regarding the approach in Sībawayhi's Kitāb, Carter (1973:146n) remarks that "[t]he Book itself is so descriptive as to be useless as a prescriptive grammar." Sībawayhi's radically descriptive approach to grammar lends itself especially well to Optimality Theory, as he often lists simultaneously occurring forms-sometimes associated with the speech of different tribes-which he then indeed ranks with value judgments such as hasan "good", 'ahsan "better", or simply "arabi "Arabic" (e.g., in the very last sentence of chapter 571), ${ }^{10}$ according to certain parameters. Here is a basic quotation applying to phonetics and phonology from the end of chapter 565 of Sìbawayhi's Kitāb, in the translation of Carter (1973:148): "I have described the letters of the alphabet [i.e., the phonemes] for you in terms of these qualities simply so that you might know what is good and permissible and what is not good and permissible to assimilate."11

In Optimality Theory, the set of forms that may reasonably be assumed to be potential surface forms is often referred to as the "richness of the base". In this paper I will use the same term in reference to the availability of simultaneously occurring forms, some of which may be true alternatives and some of which may be regional variants. In the framework of Optimality Theory, the co-occurring forms, or rather the forms that are subject to linguistic evaluation, are called "candidates".

One other central concept in Optimality Theory and elsewhere in linguistic theory is markedness. ${ }^{12}$ Broadly speaking, "marked" refers to unusual, rarer, and/or harder to pronounce forms, whereas "unmarked" refers to natural, more frequent, and/or easier to pronounce forms. The latter state is often called "well-formedness". On the segmental level, for example, velarized stops are considered "marked", whereas plain (nonvelarized) stops are considered "unmarked". On the suprasegmental level, for example, the universally "unmarked" syllable structure is CV: onset, nucleus, and no coda; other syllable structures (CVC, CVCC, CCVCC, etc.) are then considered "marked". And even within one and the same syllable type, there may be more or less marked specimens of different

10 Cf. Hārūn 4:485; http://www.hf.uio.no/east/sibawayhi/Demo/bas571.txt.htm (at 77). Sìbawayhi also frequently uses the term al-lugia al- ${ }^{c}$ arabìya al-qadima aljayyida, literally "good old Arabic". Cf. Carter 1997a:526.

${ }^{11}$ Cf. Hārūn 4:436; http://www.hf.uio.no/east/sibawayhi/Demo/bas565.txt.htm (at 7).

12 On the notion of "markedness" in Optimality Theory, cf. McCarthy and Prince 1994:1. 
quality, depending on the internal structure of syllable onset and syllable coda.

2. Optimality Theory

2.1. Basic concepts of Optimality Theory

Optimality Theory, which always aims at singling out one "optimal" form, has the potential to evaluate at least the following morphophonological parameters (cf. McCarthy and Prince 1994:2): (i) segmental harmony (unmarkedness, itself consisting of various dimensions, some conflicting); (ii) syllabic harmony (having an onset, lacking a coda); (iii) faithfulness (identity between input and output); (iv) alignment (coincidence of edges of morphological and phonological constituents); (v) metrical parsing (satisfying constraints on exhaustivity and alignment of metrical feet); (vi) template satisfaction (meeting shape or constituency requirements imposed on the reduplicated string); (vii) exactness of copying relation; and (viii) identity between the reduplicated string and the base to which it is attached.

While the references to segmental harmony and syllabic harmony are quite straightforward and unproblematic, the reference to faithfulness is interesting insofar as the concept of "underlying representation" (i.e., the "input"), which Optimality Theory purports to discard, is reintroduced, so to speak, via the backdoor. In this paper I will mostly consider the first three of the listed parameters. ${ }^{13}$

It is important to note that usually not all of these parameters can be optimized in any given form. The principle underlying this circumstance is often called the "fallacy of perfection". ${ }^{14}$ For instance, words that are entirely made up of CV syllables - this being the "optimal" syllable structure-may be lengthy or otherwise clumsy to pronounce.

\subsection{Basic tenets of Optimality Theory}

One can narrow down Optimality Theory to five basic tenets (cf. McCarthy and Prince 1994:3): (i) universality: U[niversal] G[rammar] provides a set $\{\mathrm{Con}\}$ of constraints that are universal and universally present in

\footnotetext{
13 Alignment (iv) is an especially interesting topic in Semitic linguistics in general and in Arabic linguistics in particular, and much literature has been devoted to the issue of the discontinuous structure of root morphemes and their morphophonological interaction with different vocalic patterns. Items (v) to (viii) play almost no role in the last seven chapters of the Kitāb, even though reduplication of strings does occur in Arabic, especially in quadriliteral roots. In the Ethio-Semitic languages, reduplication is an even more prominent feature.

${ }^{14}$ Cf. also Vennemann 1988:1-2.
} 
all grammars; (ii) violability: constraints are violable; but violation is minimal; (iii) ranking: the constraints of $\{\mathrm{Con}\}$ are ranked on a languageparticular basis, the notion of minimal violation is defined in terms of this ranking, a grammar is a ranking of the constraint set; (iv) inclusiveness: the constraint hierarchy evaluates a set of candidate analyses that are admitted by very general considerations of structural well-formedness; (v) parallelism: best satisfaction of the constraint hierarchy is computed over the whole hierarchy and the whole candidate set. There is no serial derivation. McCarthy and Prince (1994:4-5) conclude:

The construction of a grammar in Optimality Theory is essentially a matter of determining the proper ranking of the set of constraints $\{\mathrm{Con}\}$, and to that end the constraint tableau is a useful calculational device. A typical constraint tableau, showing the domination of constraint $\mathrm{B}$ by constraint $\mathrm{A}$, is the following:

(1) Constraint Tableau, A >> B, $/ \mathrm{in}_{\mathrm{k}} / \rightarrow k$ - cand $_{1}$

\begin{tabular}{|c|c|c|c|}
\hline \multicolumn{2}{|c|}{ Candidates } & A & B \\
\hline 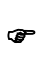 & k-cand ${ }_{1}$ & & * \\
\hline & k-cand ${ }_{2}$ & $* !$ & \\
\hline
\end{tabular}

In this tableau, it is assumed that, given the input $/ \mathrm{in}_{\mathrm{k}} /$, the generator Gen supplies at least the candidates $\mathrm{k}$-cand $\mathrm{c}_{1}$ and $\mathrm{k}$-cand $\mathrm{c}_{2}$. Constraints $\mathrm{A}$ and $\mathrm{B}$ disagree on these two candidates, and since the A-obeying $\mathrm{k}$-cand $\mathrm{C}_{1}$ is optimal, constraint A must dominate constraint B. In this and other tableaux, constraints are shown in domination order and violation-marks are indicated by “*”. The optimal candidate is called out by and fatal constraint violations are signaled by "!". Below these fatal violations, cells are shaded to indicate their irrelevance to determining the outcome of the comparison at hand.

Preservation of faithfulness and preservation of markedness are the two basic competing constraints at the heart of Optimality Theory. Then there are many other language-specific constraints that determine the morphophonological "fine-tuning" in the language under observation. Note that while constraints are supposed to be universal, their ordering is usually language-specific. Vennemann's theory of "Preference Laws for Syllable Structure" can well be considered a theoretical (even though less technical) forerunner of Optimality Theory. The concept of the constraints on certain parameters in Optimality Theory corresponds more or less to the concept of 
the preference laws in Vennemann's theory. ${ }^{15}$ These preference laws pertain to different parameters of syllable structure, a domain that Vennemann and others consider crucial for the production of an "optimal" phonological output.

Sỉbawayhi's ranking of forms can, of course, only be compared cum grano salis to the "computation" of the optimal form by means of the constraint ranking in Optimality Theory.

\section{Examples of the application of Optimality Theory}

\subsection{Different masdar forms of $\{w-t-d\}$ "to pin"}

Let us now consider an example of concurring (morphophonological and semantic) strategies and their resolution in an Optimality Theory based model. The different masāadir (sg. mașdar "infinitive") of the verb watada "to pin" aptly demonstrate the usefulness of Optimality Theory for the issues under consideration. ${ }^{16}$ The "richness of the base", to which allusion was made already above, is very apparent here; the variety of attested forms and the array of forms which Sïbawayhi assumes as theoretically desirable by far exceed the limited sets of (underlying) forms with which traditional generative morphophonology operates. According to Sïbawayhi there occurred an array of forms, ranging from watd/watid (in the Hijāz) and wadd (with the Tamīm) to tida. While the masdar forms watd and watid are superior in terms of preserving the linguistic input (especially with respect to the root consonants), the assimilated masdar form wadd is superior in terms of linguistic "naturalness", i.e., it is easier to pronounce and hence phonologically "unmarked". The latter form has the disadvantage, though, of being identical with the masdar form of the verb wadda "to love", which is, of course, not related to watada. The best ("optimal") masdar form is clearly tida, which meets the criteria of both faithfulness to the linguistic input (with respect to the second and third root consonants) and "naturalness". Such conflicting tendencies and strategies to resolve them are at the heart of the concerns of Optimality Theory.

\footnotetext{
15 For a list of these preference laws, which pertain to both the internal structure of and the contact between syllables, cf. Vennemann 1988:11.

16 Cf. Hārūn 4:474; http://wwww.hf.uio.no/east/sibawayhi/Demo/bas568.txt.htm (at 63). The root $\{\mathrm{w}-\mathrm{t}-\mathrm{d}\}$ is only attested in form II in modern times, but two (verbal) nouns are quoted, e.g., in Wehr's dictionary: watad and watid "peg". The classical dictionary Tāj al- ${ }^{c} A r \overline{u s}$, however, lists all the forms under discussion here. Sībawayhi parallelly discusses the plural forms ${ }^{c} i t d \bar{a} n$ and ${ }^{c} i d d \bar{a} n$ of the singular "atūd "one-year-old goat".
} 
Let us now move to a more technical recasting of Sïbawayhi's observations in terms of Optimality Theory. Before we begin, a number of observations are in order. Let us recall that Optimality Theory is in principle designed to single out the "optimal" surviving candidate and to throw out the rest of the candidates. In contrast to the standard application of Optimality Theory, the mașdar forms watd/watid (in the Hijāz) and wadd (with the Tamīm) ${ }^{17}$ are not disallowed, even though they are (were) regionally limited. The masdar form tida has the advantage of best preserving the root structure $\{\mathrm{w}-\mathrm{t}-\mathrm{d}\}$ in its (acoustic) output form, even though the first root consonant $\mathrm{C}_{1}(=w)$ is lost. But in the case of verbs primae wāw $\left(\mathrm{C}_{1}=w\right)$ in Arabic, the clear articulatory preservation of the last two consonants appears to be crucial for an easy recognition of the form. This observation can be technically rephrased to the extent that the output has to match the input with respect to $\mathrm{C}_{2}$ and $\mathrm{C}_{3}$. Hence this is our dominating constraint in this context, and wadd is clearly the worst candidate. Incidentally, watd is probably just as bad, as the surface pronunciation is almost certainly bound to be [watt]. ${ }^{18}$ The next constraint operating in our example is the circumstance that syllable codas with increasing sonority are universally disfavored for clear articulatory reasons. ${ }^{19}$ Such syllable codas are almost "crying" for an epenthetic vowel. The form watid may be considered the result of such an epenthetic process. ${ }^{20}$ Finally, there is the universal tendency to reduce the number of syllables with weak onsets. Let us first consider a tableau that simply demonstrates the mutually opposing forces ("constraints") of faithfulness between input and output on the one hand and phonological naturalness (unmarkedness) on the other (the opposing "candidates" here are watd and wadd):

(2) Constraint Tableau, IDENT-IO-ROOT >> *INCR-SON-COD

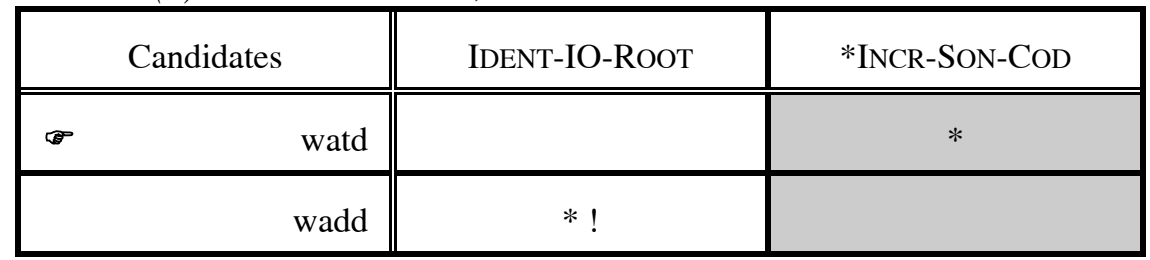

17 On this dichotomy cf. Rabin 1951:1-5.

18 There is, however, no Arabic root $*\{w-t-t\}$ with which this output form could possibly be confused.

${ }^{19}$ Cf. also Vennemann 1988:21-27.

20 One may also think of Arabic malik "king", corresponding to a "ProtoSemitic" *malk, which, by way of "segolation", surfaces also as Hebrew melek. 
The tableau illustrates that no one of the two candidates watd and wadd is "perfect". Assuming, however, that preserving the root consonants is more important than having an easy-to-pronounce syllable coda, technically speaking that IDENT-IO-ROOT dominates *INCR-SON-COD, the candidate watd emerges as the better and hence "optimal" mașdar form.

The following tableau summarizes the more complex situation involving all of the four mașdar forms:

(3) Constraint Tableau, IDENT-IO- $\mathrm{C}_{2}-\mathrm{C}_{3} \gg$ *INCR-SON-COD $>>$ *WEAK-ONS

\begin{tabular}{|lr||c|c|c|}
\hline Candidates & $\begin{array}{c}\text { IDENT-IO- } \\
\mathrm{C}_{2}-\mathrm{C}_{3}\end{array}$ & $\begin{array}{c}* \text { INCR-SON- } \\
\text { COD }\end{array}$ & $\begin{array}{c}* \text { WEAK- } \\
\text { ONS }\end{array}$ \\
\hline \hline a. & & & \\
\hline b. & tida & & & $*$ \\
\hline c. & watid & & & $*$ \\
\hline d. & watd & $* !$ & & \\
\hline
\end{tabular}

This tableau clearly illustrates the ranking of the three constraintshere one might also call them "tendencies"- that are operational in determining the "quality" of the different masdar forms. Note that the form wadd is marked with an exclamation mark that signals the "deadly" violation of the constraint IDENT-IO- $\mathrm{C}_{2}-\mathrm{C}_{3}$. The forms watd and watid incur violation marks as well, but those are not as "deadly", so to speak.

There occur at least two additional passages in chapters 565-71 of Sïbawayhi's Kitāb that can be aptly and directly recast in terms of Optimality Theory. In chapter 567, for instance, Sibawayhi mentions that in the mașdar forms of the roots $\{\mathrm{q}-\mathrm{n}-\mathrm{y}\},\{\mathrm{k}-\mathrm{n}-\mathrm{y}\}$, and $\{\mathrm{m}-\mathrm{n}-\mathrm{y}\}$, qunya (or qinya), kunya, and munya, the $y \bar{a}^{\jmath}$ may not be progressively assimilated by the nün, as this might lead to confusion with mașdar forms of verbs mediae geminatae $\left(\mathrm{C}_{2}=\mathrm{C}_{3}\right) .{ }^{21}$ The second case is addressed in the following section.

\subsection{Suprasegmental assimilation}

At the beginning of chapter 569, Sỉbawayhi notes that partial progressive assimilation with respect to velarization ( ${ }^{\mathrm{i}} i t b \bar{a} q$, literally: "covering [of the velum]") of the middle root consonant $d \bar{a} l$ is blocked in forms like /tașdīr/

${ }^{21}$ Cf. Hārūn 4:455; http://www.hf.uio.no/east/sibawayhi/Demo/bas567.txt.htm (at 39). 
for the sake of preservation of the root. ${ }^{22}$ Such partial progressive assimilation may occur, however, in cases where the consonant in question represents an infix (typically the $-t$-infix of form VIII). However, Sìbawayhi does allow for partial regressive assimilation with respect to voicedness, i.e., /tașdìr/ $\rightarrow$ [tazdīr]. Of course, one could also argue that in cases like /tașdīr/ the (first) syllable is the domain of velarization ("emphasis") and that therefore spreading of velarization is blocked beyond the $s \bar{a} d$ in the word. In any event, [tazdirr] is clearly the most harmonic and "well-formed" output. ${ }^{23}$ Technically speaking, this means that in this case the constraint that the syllable is the domain of ATR-spreading dominates the constraint of harmony with respect to voicedness, and the constraint of harmony with respect to voicedness in turn dominates the constraint of faithfulness to the root, as long as no confusion with other roots arises. Consider the following tableau:

(4) Constraint Tableau, [SYLL]-ATR > > HARM-VOICE- $\mathrm{C}_{1}-\mathrm{C}_{2}>>$ IDENT-IO-C $\mathrm{C}_{1}-\mathrm{C}_{2}$
\begin{tabular}{|lr||c|c|c|}
\hline Candidates & $\begin{array}{c}\text { [SYLL]- } \\
\text { ATR }\end{array}$ & $\begin{array}{c}\text { HARM-VOICE- } \\
\mathrm{C}_{1}-\mathrm{C}_{2}\end{array}$ & IDENT-IO- $\mathrm{C}_{1}-\mathrm{C}_{2}$ \\
\hline \hline a. & tazdir & & & $*$ \\
\hline b. & tasdiir & & $*$ & \\
\hline c. & tasdiir & $* !$ & $*$ & $*$ \\
\hline
\end{tabular}

Again, the tableau illustrates the ranking of constraints that operate in determining the quality of the "candidates" under discussion.

Let us now have a closer look at two sets of cases, first, assimilation across word boundaries, and second, assimilation and re-syllabification in forms $\mathrm{V}$ and VIII.

\subsection{Assimilation across word boundaries}

There are cases where Sībawayhi allows for assimilation and/or other phonological mergers across word boundaries, and there are cases where he discourages one from doing so. Most of Sỉbawayhi's examples belong to the

\footnotetext{
22 Cf. Hārūn 4:477-78; http://www.hf.uio.no/east/sibawayhi/Demo/bas569.txt.htm (at 66).

23 Note that in Syriac Aramaic the Semitic root $\{$ s $-\mathrm{d}-\mathrm{q}\}$ "to be faithful" surfaces also graphically as $\{\mathrm{z}-\mathrm{d}-\mathrm{q}\}$ : $z$ deq "he was faithful". Cf. also Jahn [1895-1900] 1969, vol. 2:546 (n. 5).
} 
following five classes: (5a) imperative + accusative object; (5b) genitive construct ( $\left.{ }^{\circ} i d \bar{a} f a\right)$; (5c) finite verb + subject noun or pronominal suffix governed by a preposition; (5d) nouns or prepositions with a pronominal suffix; and $(5 \mathrm{e})$ particles + finite verb. These examples show that there is a strong case in Arabic for theories of the syntax-phonology interface. ${ }^{24}$ Here are a few relevant examples from the last seven chapters of the Kitāb: ${ }^{25}$

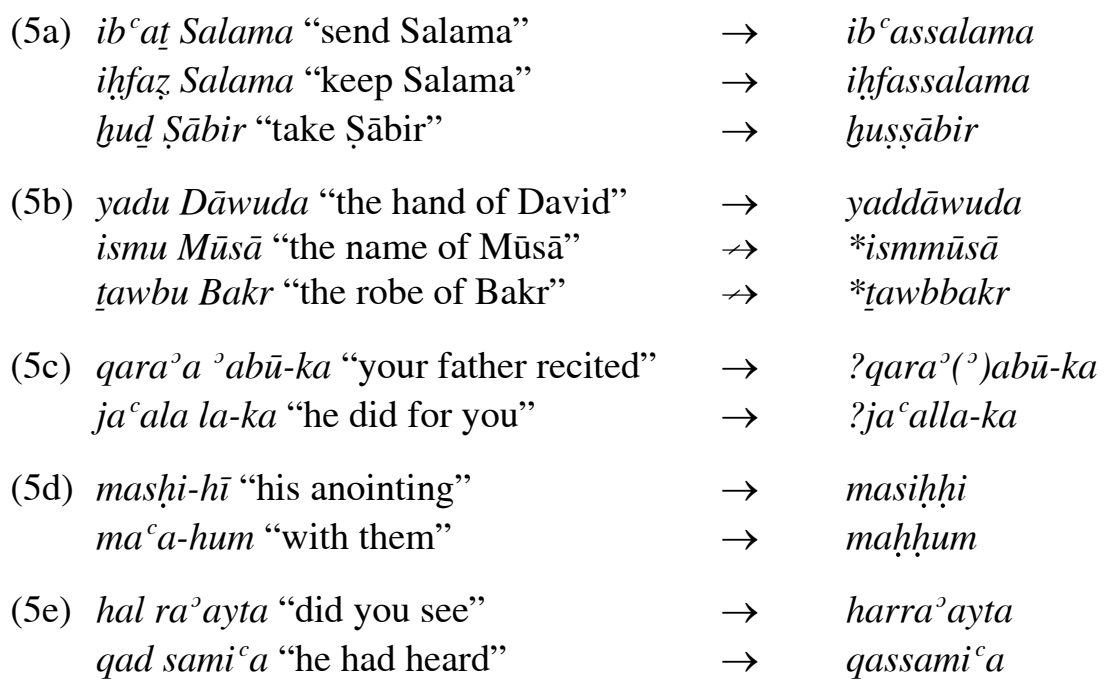

Let us regroup these examples according to their potential for phonological merger (in Sïbawayhi's eyes). First consider those cases where such mergers are classified as desirable (6a). Then consider those cases where such mergers are possible à la limite but not really called for (6b). And finally consider thoses cases where phonological merger is discouraged if not disallowed (6c). Here are the regrouped examples:

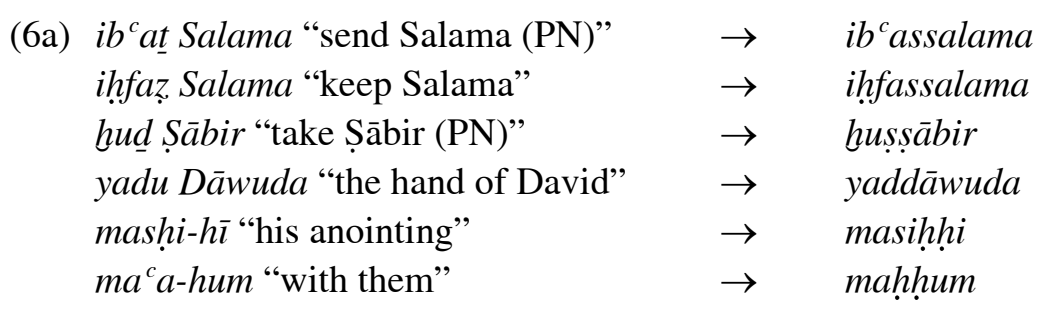

\footnotetext{
${ }^{24}$ Cf. Inkelas and Zec 1995.

25 These examples appear passim at different places in chapters 565-71, depending on the place of articulation of the assimilated consonant. Cf. also Al-Nassir 1993:56-80.
} 
hal ra"ayta "did you see

qad samica "he had heard"

(6b) jacala la-ka "he did for you" $q a r a^{\circ} a^{\circ} a b \bar{u}-k a$ "your father recited"

(6c) ismu Mūsā "the name of Mūsā" tawbu Bakr "the robe of Bakr"

$$
\begin{array}{ll}
\rightarrow & \text { harra ayta } \\
\rightarrow & \text { qassami } a \\
\rightarrow & \text { ?jacalla-ka } \\
\rightarrow & \text { ?qara }\left(^{\circ}\right) \text { abu } \overline{-} \text {-ka } \\
\rightarrow & \text { *ismmūsa } \\
\rightarrow & \text { *tawbbakr }
\end{array}
$$

Cases (6a) to (6c) can be most conveniently analyzed in terms of preference laws for syllable structure. In case (6a) all of the first constituents end in a single consonant or in a CV syllable preceded by a vowel, except for the more complicated case mashi-hi "his anointing". Thus there is no difficulty in achieving the desired phonological mergers, be it by means of regressive assimilation, elision of a vowel, or the true phonetic merger as apparent in maḥum "with them". The possible haplology in case (6b) can be compared to the case of yadu Dāwuda $\rightarrow$ yaddāwuda. In case (6c) such a phonological merger, especially the elision of the last vowel in the first constituent is not possible, as such an elision would yield an impossible syllable structure, or rather three adjacent consonants (a disallowed sequence/consonant cluster in Arabic). This is so because the last CV syllable of the first constituent is preceded by a CVC syllable.

Sỉbawayhi's explanations of 'idḡam are rather complicated and not always consistent, especially as he has no concept of the syllable at all. It is, however, a fascinating feature in the Kitāb that Sìbawayhi also discusses what we nowadays would call "starred" forms. For instance, Sïbawayhi rules out the following potential phonological merger: buyyina la-hum "it was explained to them" $\rightarrow$ *buyyinna-hum. ${ }^{26}$ By contrast, the phonological merger $j a^{c}$ ala la-ka "he did for you" $\rightarrow j a^{c}$ alla-ka is approved by Sỉbawayhi. Now, while the syllable structure would allow for the phonological merger in both cases, it is clear that in the merger buyyina la-hum "it was explained to them" $\rightarrow$ *buyyinna-hum the information about the preposition would be lost. So again we are looking at the conflicting forces, i.e., conflicting constraints, of phonological naturalness and well-formedness on the one hand, and faithfulness to the linguistic input on the other hand, and Optimality Theory provides an ideal way to represent this formally. Here are

26 Cf. Hārūn 4:472; http://www.hf.uio.no/east/sibawayhi/Demo/bas568.txt.htm (at 60). 
the representative tableaux:

(7) Constraint Tableau, IDENT-IO-PREP $>>$ IDENT-IO-ROOT $>>* \mathrm{C}_{\mathrm{i}} \mathrm{V}-\mathrm{C}_{\mathrm{i}} \mathrm{V}$

\begin{tabular}{|c|c|c|c|}
\hline Candidates & IDENT-IO-PREP & IDENT-IO-ROOT & ${ }^{*} \mathrm{C}_{\mathrm{i}} \mathrm{V}-\mathrm{C}_{\mathrm{i}} \mathrm{V}$ \\
\hline $\mathrm{ja}^{\mathrm{c}}$ alla-ka & & & \\
\hline $\mathrm{ja}^{\mathrm{c}}$ ala la-ka & & & $* !$ \\
\hline
\end{tabular}

(8) Constraint Tableau, IDENT-IO-PREP >> *IDENT-IO-ROOT >> *CV-CV

\begin{tabular}{|c||c|c|c|}
\hline Candidates & IDENT-IO-PREP & IDENT-IO-ROOT & $*$ CV-CV \\
\hline \hline buyyina la-hum & & & $*$ \\
\hline buyyinna-hum & $* !$ & & \\
\hline
\end{tabular}

It is noteworthy that *buyyinna-hum also runs counter to the strength assimilation law ("If Consonantal Strength is assimilated in a syllable contact, the Consonantal Strength of the stronger speech sound decreases." ${ }^{27}$ ), as the nasal $n$ has a slightly higher consonantal strength on the sonority scale than the lateral liquid $l$. In the Qur ${ }^{\circ} \bar{a}$, one finds the expected pattern of regressive assimilation in the form yubayyilla-na $(<$ yubayyina la-nā) "so that he explain to us". ${ }^{28}$

\subsection{Assimilation and re-syllabification in forms V, VI, VII, and VIII}

Sïbawayhi quotes a number of alternative forms of the standard diatheses V, VI, VII, and VIII, all of which feature assimilation and re-syllabification. ${ }^{29}$ The situation in forms V and VI is relatively straightforward. What often occurs is the already mentioned syllable ellipsis in cases like $f a-l \bar{a}$ (t)tanājaw! "don't whisper to each other" ${ }^{30}$ Sībawayhi also quotes assimi-

27 Cf. Vennemann 1988:35 in reference to Murray’s (1982:171, 182-82) Progressive Assimilation Law.

${ }^{28}$ Q 2:68-70 (3 times). Cf. also Ungnad 1932:67 on the development of the Syriac Aramaic root $\{\mathrm{n}-\mathrm{t}-\mathrm{n}\}$ "to give" to $\{\mathrm{n}-\mathrm{t}-\mathrm{l}\}$ under the influence of the enclitic preposition $l$ governed by this verb.

${ }^{29}$ Cf. also Fischer 1982:38-39, 44 and Edzard 1998:158-59, regarding the old attestation of these forms.

${ }^{30}$ Cf. Hārūn 4:440; http://www.hf.uio.no/east/sibawayhi/Demo/bas566.txt.htm (at 12). Cf. also the forms fa-ddāra'tum (<tadāra tum) "and you (m. pl.) contended" (Q 2:72) and izzayyanat (< tazayyanat) "she decorated herself" (Q 10:24). 
lated verbs of form VII (standard $i n C_{1} a C_{2} a C_{3} a$ ) that are not part as such of the standard language, e.g., immaha $\bar{a}$ "he was effaced". ${ }^{31}$ In the quoted examples of forms VI and VII the dominating constraint is faithfulness to the input of the root consonants. This constraint is in turn dominated by the constraint of a well-formed syllable structure; still, the assimilated element of the diathetic prefix is recognizable as such. Here are derivations of the nonstandard examples of forms V, VI and VII:

$$
\begin{array}{lll}
\text { (9a) tatamannawna "you (m. pl.) wish" } & \rightarrow & \text { tamannawna } \\
\text { fa-lā tatanājaw! "don't whisper to each other" } & \\
& \rightarrow & \text { fa-lā }(t) \text { tanājaw! } \\
& \rightarrow & \text { immahāa }
\end{array}
$$

The situation in form VIII is far more complicated, as Síbawayhi cites an array of forms that by far exceeds the well-known cases of partial and total assimilation that may occur in form VIII. ${ }^{32}$ Here is an overview of the nonstandard output forms (m. pl. of perfect, imperfect, and participle) of the verb $\{\mathrm{q}-\mathrm{t}-1\}$ "to kill" in form VIII ("to kill each other") that normally do not undergo any assimilatory change: 33

$$
\begin{array}{lll}
\text { (9b) } \text { iqtatalū } & \rightarrow & \text { qittalū } \\
\text { yaqtatilūna } & \rightarrow & \{\text { yaqattilūna, yaqittilūna }\} \\
\text { muqtatilūna } & \rightarrow & \{\text { muqattilūna, muqittilūna }\}
\end{array}
$$

Note the ordering in the set brackets, which indicates that people who say yaqattilūna will also say muqattilūna, and so on. Interestingly, these forms amount to an assimilation of the infixes (-t-) to the middle radical, as is also obvious in the participle murtadifüna $\rightarrow$ muruddifüna "[they (m.) are] directly following", which furthermore features vowel harmony with respect to $u .{ }^{34}$ Again, the driving force or constraint behind these forms appears to be the wish to avoid a sequence of equal syllables. As in the previous examples, next

These latter forms, both of which exhibit a hamzat al-wașl, are formed according to an $i t C_{1} a C_{2} C_{2} a C_{3} a$ pattern.

${ }^{31}$ Cf. Hārūn 4:455; http://www.hf.uio.no/east/sibawayhi/Demo/bas567.txt.htm (at 39).

32 Another interesting point here is the internal logical structuring of Sỉbawayhi's description: there are many statements to the effect that people who say $\mathrm{X}$ will also say $\mathrm{Y}, \mathrm{X}$ referring to a finite verbal form and $\mathrm{Y}$ to a participle.

${ }^{33}$ Cf. Hārūn 4:438; http://www.hf.uio.no/east/sibawayhi/Demo/bas566.txt.htm (at 10).

${ }^{34}$ Cf. Hārūn 4:443-44; http://www.hf.uio.no/east/sibawayhi/Demo/bas566.txt.htm (at 17). 
comes the faithfulness to the input of the root consonants. As a result, the underlying form of the diathesis (VIII) is quite opaque in these cases.

Forms with total phonological merger (progressive, regressive, or "reciprocal" assimilation, i.e., "compromise" on a phonetically intermediate consonant) arise in the case of verbs whose first radical is a voiced and/or velarized sibilant or a voiced and/or velarized alveolar stop: ${ }^{35}$
(9c) istabara "he was patient" $\quad \rightarrow \quad$ issabara idtajara "he was angry" $\quad \rightarrow \quad$ iddajara ižtalama "he suffered injustice" $\quad \rightarrow \quad$ ițtalama ${ }^{36}$

Again, the cited examples constitute an interesting case for the competing constraints of input-output faithfulness on the one hand, and phonological well-formedness on the other hand. Here is a tableau for the different cited participles of $\{\mathrm{q}-\mathrm{t}-\mathrm{l}\}$ of form VIII:

(10) Constraint Tableau, $* \mathrm{C}_{\mathrm{i}} \mathrm{V}-\mathrm{C}_{\mathrm{i}} \mathrm{V}>>$ HARM-VOWEL $>>$ IDENT-IO-DIATH

\begin{tabular}{|lr||c|c|c|}
\hline \multicolumn{2}{|c|}{ Candidates } & $*{ }_{\mathrm{i}} \mathrm{V}-\mathrm{C}_{\mathrm{i}} \mathrm{V}$ & HARM-VOWEL & IDENT-IO-DIATH \\
\hline \hline a. & muqittil & & & $*$ \\
\hline b. & muqattil & & $*$ & \\
\hline c. & muqtatil & $* !$ & $*$ & $*$ \\
\hline
\end{tabular}

As happened already, the avoidance of a sequence of equal syllables appears to be the dominating constraint in the production of the dialectal surface forms of these participles. A point which Sìbawayhi does not raise in this context is the possible confusion of the non-standard participles of form VIII $\left(m u C_{1} t a C_{2} i C_{3}\right)$ with regular participles of form II $\left(m u C_{1} a C_{2} C_{2} i C_{3}\right)$. It is quite likely that the avoidance of such a confusion is the very rationale behind the "compensatory" effect of vowel harmony in forms like muruddif and muqittil. ${ }^{37}$

\footnotetext{
${ }^{35}$ Cf. also "classical" iddakara (/id-t-akara/) "he remembered", ittahada (/i ${ }^{3}$-tahada/) "he took on", etc.

${ }^{36}$ Remember that for Sỉbawayhi /t// is [+ voiced]. Voicedness thus prevails in this form. The standard form is izzalama, though.

${ }^{37}$ Compensatory effects, e.g., phonological drag chains and push chains, are a quite normal phenomenon from the perspective of a linguistic model that views language change as a teleological process, as is the case in Optimality Theory.
} 


\section{Summary}

The central idea of Optimality Theory is that surface forms of language reflect resolutions of conflicts between competing constraints. A surface form is "optimal" if it incurs the least serious violations of a set of constraints, taking into account their hierarchical ranking. Languages differ in the ranking of constraints, and any violations must be minimal. Sībawayhi's presentation and discussion of contemporary Arabic data, in phonetics, phonology, and elsewhere, is in harmony with these principles. It illustrates and supports an explanatory approach to Arabic morphophonology in terms of naturalness and preference theory in general, and of Optimality Theory in particular.

\section{References}

5.1. Editions, translations, and e-editions of (parts of) Sībawayhi's Kitāb

Carter, Michael, Alexander Matveev, and Lutz Edzard. Internet site http:// www.hf.uio.no/east/sibawayhi/HomePage/index.htm.

Derenbourg, Hartwig. Le livre de Sībawayhi. 2 vols. Paris, 1881-89; reprint Hildesheim, 1970.

Jahn, Gustav. Sïbawaihis Buch über die Grammatik übersetzt und erklärt. 2 vols. Berlin, 1895-1900; reprint Hildesheim, 1969.

Kitāb Sībawayhi. 2 vols. Būlāq, 1898-1900; reprint Baghdad, 1965.

Kitāb Sībawayhi. Ed. Muhammad 'A Abd al-Salām Hārūn. 5 vols. Cairo, 1968-77; 2nd ed. Cairo, 1977.

\subsection{Secondary sources}

Bakalla, M. 1982. Ibn Jinnī, An Early Muslim Phonetician: An Interpretative Study of His Life and Contributions to Linguistics. London, Taipei.

Bohas, G. and J. Guillaume. 1984. Étude des théories des grammairiens arabes. Vol. I. Morphologie et phonologie. Damascus.

Bravmann, M. 1934. Materialien und Untersuchungen zu den Phonetischen Lehren der Araber. Göttingen.

Carter, M. 1973. An Arab Grammarian of the Eighth Century A.D., Journal of the American Oriental Society 93:146-57.

1997a. Sỉbawayhi. In The Encyclopaedia of Islam (new edition), 9:524-31.

1997b. The Platonic Edition: Some Consequences of Computer

Editing for Text-Based Scholarship in Arabic Grammar. Manuscripta Orientalia 3, no. 4:54-58.

Edzard, L. 1991. Semitic Phonology and Preference Laws for Syllable Struc- 
ture. In Semitic Studies in Honor of Wolf Leslau, ed. A. Kaye, vol. 1:397410. Wiesbaden.

1998. Polygenesis, Convergence, and Entropy: An Alternative Model of Linguistic Evolution Applied to Semitic Linguistics. Wiesbaden.

Fischer, W. 1982. Das Altarabische in islamischer Überlieferung. In Grundriß der arabischen Philologie. Band 1: Sprachwissenschaft, ed. W. Fischer, 37-50. Wiesbaden.

Fleisch, H. 1958a. La conception phonétique des Arabes d'après le Sirr Șin $\bar{a}^{c} a t$ al-I ${ }^{c} r a ̄ b$ d'Ibn Ğinnī. Zeitschrift der Deutschen Morgenländischen Gesellschaft 108:74-105.

1958b. Mağhūra, mahmūsa: examen critique. Mélanges de l'Université Saint-Joseph 35:193-210.

. 1971. Idghām. In The Encyclopaedia of Islam (new edition), 3:1013-14.

Hary, B. 1992. Multiglossia in Judeo-Arabic: With an Edition, Translation, and Grammatical Study of the Cairene Purim Scroll. Leiden.

Hoberman, R. 1989. Parameters of Emphasis: Autosegmental Analyses of Pharyngealization in Four Languages. Journal of Afroasiatic Languages 2, no. 1:73-97.

1995. Current Issues in Semitic Phonology. In The Handbook of Phonological Theory, ed. J. Goldsmith, 839-47. Cambridge, Mass.

Hooper, J. 1976. An Introduction to Natural Generative Phonology. New York.

Humbert, G. 1995. Les voies de la transmission du Kitāb de Sībawayhi. Leiden, New York, Cologne.

Inkelas, S. and D. Zec, 1995. Syntax-Phonology Interface. In The Handbook of Phonological Theory, ed. J. Goldsmith, 535-49. Cambridge, Mass.

Kager, R. 1999. Optimality Theory. Cambridge.

Levin, A. 1994. Sìbawayhi's Attitude to the Spoken Language. Jerusalem Studies in Arabic and Islam 17:204-43.

— 1999. The First Book of Arabic Dialectology: Sībawayhi's al-Kitāb. Jerusalem Studies in Arabic and Islam 23:208-20.

McCarthy, J. 1991. Guttural Phonology. In Perspectives on Arabic Linguistics III. Papers from the Third Annual Symposium on Arabic Linguistics, ed. B. Comrie and M. Eid, 63-92. Amsterdam, Philadelphia.

McCarthy, J. and A. Prince. 1994. The Emergence of the Unmarked: Optimality in Prosodic Morphology. Ms., University of Massachusetts, Amherst, and Rutgers University. Rutgers Optimality Archive \#ROA-130594, http://ruccs.rutgers.edu/roa.html.

. 1995. Prosodic Morphology. In The Handbook of Phonological 
Theory, ed. J. Goldsmith, 318-66. Cambridge, Mass.

Murray, R. 1982. Consonant Developments in Pāli. Folia Linguistica Historica 3:163-84.

Al-Nassir, A. 1993. Sìbawaih the Phonologist: A Critical Study of the Phonetic and Phonological Theory of Sïbawaih in His Treatise "AlKitāb. "London.

Odisho, E. 1988. Sībawayhi's Dichotomy of Majhūra/Mahmūsa Revisited. Al- ${ }^{c}$ Arabiyya 21:81-91.

Prince, A. and P. Smolensky. 1993. Optimality Theory: Constraint Interaction in Generative Grammar. Ms., Rutgers University and University of Colorado, Boulder.

Rabin, C. 1951. Ancient West-Arabian. London.

Schaade, A. 1911. Sībawaihi's Lautlehre. Leiden.

Semaan, K. 1968. Linguistics in the Middle Ages: Phonetic Studies in Early Islam. Leiden.

Steiner, R. 1977. The Case for Fricative-Laterals in Proto-Semitic. New Haven.

Troupeau, G. 1958. Le commentaire d'al-Sīrāfĩ sur le chapitre 565 du Kitāb de Sībawayhi. Arabica 5:168-82.

- 1976. Lexique-Index du Kitāb de Sïbawayhi. Paris.

Ungnad, A. 1932 (2nd ed.). Syrische Grammatik. Munich.

Vennemann, T. 1983. Causality in Language Change: Theories of Linguistic Preference As a Basis for Linguistic Explanations. Folia Linguistica Historica 6:5-26.

1988. Preference Laws for Syllable Structure and the Explanation of Sound Change. Berlin.

Versteegh, K. 1997. The Arabic Language. Edinburgh.

Zawaydeh, B. 1997. On an Optimality-Theoretic Account of Epenthesis and Syncope in Arabic Dialects. In Perspectives on Arabic Linguistics X. Papers from the Tenth Annual Symposium on Arabic Linguistics, ed. M. Eid and R. Ratcliffe, 191-213. Amsterdam, Philadelphia. 